\title{
ACCOUNTING PRINCIPLES IN CORPORATION LAW
}

\author{
WiLLIaM P. HackNeY*
}

INTRODUCTION

The interrelationship between law and accounting is intricate and confusing. It is not enough to say simply that accountants must turn to lawyers for answers to legal questions and lawyers to accountants for answers to accounting questions, for the problem often is whether and to what extent a question is one of law or accounting or a mixture of both. When state corporation statutes speak in terms of capital, surplus, profits, retained earnings, depreciation, and the like-the phrases frequently standing stark, without definition-to what extent will accounting usages and practices control the legal question? When such terms are defined by statute or decision, to what extent must the legal definitions be reflected in the financial statements prepared by accountants? When federal securities laws require the dissemination of financial information, and prohibit misleading statements, to what extent will accounting practices or state corporation laws determine the question of full and adequate disclosure?

Investigation will show that accounting terms in law are not single, static concepts, equally applicable for all purposes. A state corporation law's definition of surplus or profits will not be controlling in the computation of "taxable income"; "full disclosure" under securities laws is not simply a matter of disclosing profits available for dividends or taxable income; none of these concepts will dictate the method of computing return on capital in the administrative determination of fair and reasonable rates to be charged by public utilities; and the interpretation of accounting terminology in private contracts is primarily a question of intent of the parties, which may or may not have any particular relation to accounting concepts appropriate for other purposes.

The foregoing are a few of the instances where the law requires interpretation and computation in an accounting framework. The accounting profession, however, is concerned primarily with a nonlegal goal: the preparation of financial statements that "fairly present" the financial condition and results of operations of an enterprise, not for any single purpose required by law, but for the general purpose of informing investors, creditors, consumers, employees, and other interested parties. ${ }^{1}$

- A.B. 1946, Princeton University; LL.B. I95I, Harvard University. Member of the firm of Reed, Smith, Shaw \& McClay, Pittsburgh, Pa.

${ }^{1}$ Of course, one of accountancy's primary objects is the supplying of financial data and other information to management, but accounting principles as such are only concerned with the "standards for meeting fiduciary responsibilities to investors and others, outside of management, having bona fide interests in the business entity." Paul Grady, Inventory of Generatiy Accepted Accounting 
This is not to say that the accounting profession does not also serve helpfully in such legal matters as the solution of rate-fixing problems or the definition and determination of taxable income, ${ }^{2}$ but the primary aim of accountancy in recent decades has been to establish principles controlling the preparation of "general purpose" financial statements that do not necessarily serve the needs of any particular legal objective.

It will be helpful for lawyers to analyze the accountants' own views of the accounting function with relation to "general purpose" financial statements before proceeding to investigate the relationship of the law thereto.

\section{A. The Accounting Function}

Accounting is defined by accountants themselves as the art of recording, classifying, interpreting, and summarizing, in a significant manner and in terms of money, transactions and events that are, in part at least, of a financial character and of supplying dependable and significant information with respect thereto. ${ }^{3}$ Accountants are agreed upon the following general principles or concepts applicable to this process:

(I) "General purpose" financial statements consist essentially of $(a)$ a balance sheet, which reflects a financial position at a moment of time, and $(b)$ a statement or statements of income and surplus, which reflect the results of operations over a stated period of time, together with $(c)$ notes, which reveal additional financial information not properly or necessarily contained in the balance sheet and income and surplus statements themselves. These statements of financial position and results of operations are fundamentally related in that they articulate with each other and rest upon the same underlying data.

(2) Financial statements are first of all representations of management, not of the independent accountant whose report or opinion (commonly called "certificate") may accompany the statements. ${ }^{4}$ The independent accountant's function (the function of "auditing") is to (a) review and test ("audit") the accuracy of management's methods of gathering and reporting the bookkeeping entries that constitute the raw material of accounting, (b) independently review management's financial statements and the principles followed in their preparation, and $(c)$ issue a report

PrInciples FOR Business ENterprises 5 (AICPA Accounting Research Study No. 7, 1965) [hercinafter cited as Research STUDY No. 7].

It is anomalous that in the last 30 years accountants seem to have adopted the position that the interpretation of state corporation laws and the determination of funds available for dividends involvc almost purely legal questions, while similar problems in the areas of rate-fixing and income taxation arc attacked with vigor as accounting or mixed accounting and legal matters. Sec CommurteE on TeRMINOLOGY, AICPA, Review and Résumé to (Accounting Terminology Bull. No. $x, 1953$ ) (this terminology bulletin and others are hereinafter cited as Terminology Bull. No. -]; Researcr Study No. 7, at 2-5.

${ }^{3}$ The definition is taken from Terminologx Bull. No. $r$, at 9 , modified slightly along the lines suggested in RESEARCH Study No. 7 , at 4 .

${ }^{4}$ Comimitree on Auditing Procendre, AICPA, Auditing Standards and Procedures 9-io (Statcment on Auditing Procedure No. 33, 1963); Research Study No. 7, at 8, 12; Louis H. Rappaport, SEC Accounting Practice and Procedure 2.I0-.ix (2d ed. r963). 
on the financial statements containing a reference to the scope of the audit performed and stating a conclusion (as a matter of opinion) as to whether the balance sheet "fairly presents" the financial condition of the firm and the income and surplus statements "fairly present" the results of its operations, all "in accordance with generally accepted accounting principles." The phrase "generally accepted auditing standards" embraces the full scope of the accountant's functions, together with standards of training and proficiency, independence of mental attitude, and due professional care to be exercised; while the phrase "generally accepted accounting principles" is narrower, and encompasses only a portion of the auditor's function: the exercise of judgment as to the accounting principles followed and the overall fairness of the end-product statements that are issued to the public. ${ }^{5}$

(3) It is essential for the layman to keep in mind that the preparation of financial statements is not just a matter of bookkeeping or of accuracy or technical proficiency in keeping records. "Financial condition" and "results of operations" relate to questions of value and income, concepts that are impossible to define with any accuracy or in a manner free from controversy. Bonbright's two-volume work on The Valuation of Property is evidence enough of the difficulty of isolating any meaningful definition of value for any specific purpose, and he concludes that not even the concept of value has been the subject of so much dispute among economists as has the concept of income. ${ }^{6}$

Accounting is thus not a science in the sense that "correct" accounting principles for the determination of income or financial condition exist and may ultimately be discovered or may be derived from or proven by the laws of nature or inductive or deductive logic. Accounting, rather, is said to be an art, and principles are asserted and justified on the grounds of serving some principal aim or objective, such as usefulness or fairness of presentation.?

\footnotetext{
See Commtree on Auditing Procedure, op. cit. supra note 4, chs. 2, 7.

2 James C. Bonbright, The Valuation of Property 897 (I937).

${ }^{7}$ See, e.g., Subcommitee on Independent Audits and Audit Procedure, Comm. on Stock List, New Yonk Stock Exchange, Report 2 (I939): "It may seem elementary, but it is apparently necessary and important to emphasize again and again that financial statements of industrial companies are not statistical presentations of fact." See also Study Group on Business Income, Changing Concepts of Business INCOME I8-19 (1952) ("Indeed, the question, What is the business income for a year of a corporation, is one that may be said to bear a fairly close analogy to the question, What is the color of the chameleon? ... And the corporation has in relation to income an even greater capacity for adaptation than the chameleon has in relation to color."); HeNRX R. HAtrield, Surplus and Dividends 38 (1943) ("It has been said that nine-tenths of all balance-sheet values are estimates"); TERMINOLOGY Buli. No. I, at 9-Io; Commitee on Accounting Procedure, AlCPA, Restatement and Revision of Accounting ReseArch Bulletins 59 (Accounting Research Bull. No. 43, I953) [this research bulletin and others are hereinafter cited as ResenRch BuLl. No. - ]. Accounting has been compared with the common law since "neither is static in concept and both have the flexibility and capacity for growth and adaptation to meet the changing problems of a complex business community." RESEARCF STUDY No. 7 , at 5. See George S. Hilis, The Law of Accounting and Financial Statements 3 (1957); address by Andrew Barr at N.Y.U. Graduate School of Business Administration, April 10, 1963, quoted in J. Accountancy, July 1963 , p. 69. On the other hand, the analogy has been criticized in so far as it implies that accounting principles can only be developed on a case-by-case basis. ReEd K. Storey, The Senrch for Accounting Prunciples 64 ( $(964)$.
} 


\section{B. Generally Accepted Accounting Principles}

Financial statements must, as stated above, be prepared and presented in accor. dance with "generally accepted accounting principles" ("g.a.a.p.") before the independent accountant's favorable opinion thereon will be given. It has never been very clear how principles become "generally accepted," and no definitive answer has ever been given to the question of precisely which principles may be said to be "generally accepted," although the matter of their specific identification and justification has been a concern of the accounting profession ever since the early r930s.

The term arose as the result of correspondence between the American Institute of Accountants (AIA) and the New York Stock Exchange, in consultation with the Controllers' Institute of America, when the accounting profession first began in an extensive way to improve and unify accounting practices. A list of five "broad principles" that had won "fairly general acceptance" was first set down in the AIA-NYSE correspondence, ${ }^{8}$ and accountants themselves have ever since been urging the necessity of amplifying this list and codifying a set of "g.a.a.p." that would improve financial accounting and reporting and also reduce the number of acceptable alternative methods and procedures. Attempts were made by individual writers ${ }^{9}$ and the professional associations to accomplish these dual objectives but without substantial success. The approach of the American Accounting Association (AAA), ${ }^{10}$ the organization primarily of teaching accountants, has been called comprehensive and theoretical and has been without substantial acceptance in practice, while the approach of the American Institute of Certified Public Accountants (AICPA), the successor to the AIA as the organization primarily of practicing accountants, has been labeled a "brush-fire" approach, being characterized by pronouncements upon particular controversial issues without comprehensive or integrated philosophy or conceptual integration. ${ }^{11}$

Until recently, the criteria of "general acceptance" appear to have been that a principle either have wide support in current practice, so as to be virtually unanimously acceptable without question, or have "substantial authoritative support," which is construed to mean approval by one or more of the following: a committee of one of the major national professional accounting organizations, such as the AICPA or the AAA; state or federal regulatory authorities; books of individual

${ }^{8}$ AIA, Audits of Corporate Accounts 12-14 (r934).

${ }^{\circ}$ E.g., Stephen Gilman, Accounting Concepts of Profit (1939); A. C. Littreton, Structure of Accounting Theory (I953); Thomas H. Sanders, Henry R. Hatpield \& Underhili Moore, A Statement of Accounting Principles (1938).

${ }^{10}$ E.g., AAA, A Tentative Statement of Accounting Principles Affecting Corporate Reponts (I936); AAA, Accounting Principles Underlying Corporate Financiar Statements (1941). These documents, together with a number of supplements and revisions thereto, are published by the $A A A$ in a pamphlet under the title Accounting and Reporting Standards for Corporate Financiat. StateMents \& Preceding Statements \& Supplements (I957).

${ }^{11}$ Storey, op. cit. supra note 7, at 40-52. See id. at 24-25; A. C. LitTleton \& V. K. Zimmeroman, Accounting Theory: Continuity and Change I39-44 (1962). 
accountants whose works are widely read and highly regarded; or requirements and views of stock exchanges, industry associations, and the like. ${ }^{12}$ The question is one of degree, and today in areas of controversy only the imprimatur of the Institute itself will guarantee a principle's qualification as "generally accepted."

It is significant that legal recognition is not generally sufficient today to qualify an accounting practice for inclusion in "g.a.a.p." In the accounting view, legal relationships existing between parties constitute part of the background data on which accounting reports, but law itself does not dictate accounting principles by which such reports are put together. Although the law may control specified types of accounting for specified purposes, such as the determination of the legality of dividends, the computation of income for tax purposes, rate regulation of public utilities, and interpretation of accounting terminology used in private contracts, these areas constitute "special-purpose" accounting, toward which "g.a.a.p." are not specifically directed. ${ }^{13}$

In recent years the AICPA has embarked upon a controversial and ambitious program of research and codification with the continued double aim of improving practices while reducing the number of acceptable alternatives. ${ }^{14}$ Research studies

\footnotetext{
${ }^{13}$ See Research Study No. 7, ch. 3; Robert H. Montgomery, Audiring 76-78 (8th ed. I957). It is clear, however, that a principle may be "generally accepted" even if not "generally followed": "Thus, while one concern may follow an accounting procedure distinctly peculiar to itself, this in no way disqualifies it from being accorded a recognition of following 'generally accepted accounting principles,' if the broad principle which that procedure seeks to implement is, in fact, a generally accepted one." Robert H. Montgomery, Auditing 66-67 (7th ed. 1949).

${ }^{10}$ In prior years, the law was considered one of the essential sources dictating in part the development of good accounting practice. Dicksee's pioneering work entitled Goodwill (r900) commenced with an introductory chapter consisting of an "outline of the law relating to good will." Hatfield's and May's writings are sprinkled with case citations and quotations from opinions. Dean spoke in 1949 of the circuity of reference when a lawyer, "asked to pass upon a legal concept deriving its meaning, in whole or part, from accounting concepts, in the absence of statutory authority or case law, turns to the accountant for help in determining ['g.a.a.p.']," while he in turn is met with a request from the accountant for advice as to "the applicable legal principles to be followed" in the same determination. Arthur H. Dean, An Incuiry Into the Nature of Business Income Under Present Price Levels 49 (I959). The current view is that

"broad [accounting] principles must transcend the historical limitations of profits 'available for dividends' or 'subject to income tax.' This is not to say that the effects of dividends and of taxes should be ignored; to do so would ignore a significant part of the environment in which accounting operates. Rather the task is to formulate those principles which will enable us to measure the resources held by specific entities and the related changes before consideration of taxes and dividends. The measurements should be independent of the dividend and the tax questions but, at the same time, should facilitate the solution of those questions . . .."

Robert T. Sprouse \& Maurice Moonitz, A Tentative Set of Broad Accounting Princtples for Business Enterprises io (AICPA Accounting Research Study No. 3, 1962) [hereinafter cited as RESEARCY STUdY No. 3].

14 The Council of the AICPA has stated that the objective of its research program is "to advance the written expression of what constitutes generally accepted accounting principles. . . This means something more than a survey of existing practice. It means a continuing effort to determine appropriate practice and to narrow the areas of difference and inconsistency in practice." AICPA, ORGanization AND Operation of the Accounting Research Program and Related Activities 9 (I959). In his definitive work on the development of accounting principles in the United States, Reed K. Storey, Director of Accounting Research for the AICPA, has written that the professional literature since 1930 consistently
} 
sponsored by the AICPA proposing radical changes in accounting principles have focused the attention of the Accounting Principles Board on the contradiction inherent in a statement of principles that purports to be a statement of something that is "generally accepted" and at the same time attempts to improve existing n; rictices-to attempt to impose as "generally accepted" what ought to be rather than what is. The approach of the Institute has traditionally been that the authority of the pronouncements of its committees rested upon their "general acceptability," with departures allowed upon the assumption of the burden of justifying the alternative practice used. The Institute recently changed this policy, and bulletins and opinions of Institute committees will after December $3 \mathrm{I}$, 1965, automatically be deemed to constitute "g.a.a.p.", while departures therefrom will be required to be disclosed either in footnotes or in audit reports. ${ }^{15}$

The question arises as to how an accountant should report on statements that are in accord with "g.a.a.p." but in his opinion do not "fairly present" the company's financial condition or results of operations. The question may be rephrased by asking whether, in the accountant's standard form of report, ${ }^{10}$ the phrase "in accordance with generally accepted accounting principles" qualifies and limits the meaning of "fairly presents," or whether the accountants must always be satisfied that the statements under review both fairly present the company's financial condition and results of operations (without regard to accounting principles) and are

"gives the impression that ( 1 ) financial accounting and reporting needs to be improved, (2) too many alternative methods and procedures are being used, (3) some limitation of the number of accepted alternatives is desirable, and (4) at least part of the solution lies in more carcfully specifying the "principles of accounting.' " STOREY, op. cit. supra note 7 , at 3 .

${ }^{15}$ It was originally suggested in 1957 by the President-elect of the AICPA that bulletins approved by the Institute's Council should be binding upon AICPA members. This proposal was rejected. The Accounting Principles Board (APB) and Accounting Research Division were established by the AICPA in 1959, with the announced objective of narrowing the areas of difference and inconsistency in practice. The APB in July 1963 announced its intention to intensify a program aimed at "narrowing the areas of difference in accounting treatments of similar transactions by companies in similar circumstances." News Report, J. Accountancy, Aug. 1963, p. 9, at 14. The Executive Committce of the AICPA then attracted considerable public attention in its proposal early in 1964 that APB pronouncements be considered as constituting the only accepted principle, so that any variation would have to be noted as not being presented in accord with "g.a.a.p." Executive Comm., AICPA, StAtus of Pronouncements of Accounting Principles Board (1964), which recounts the foregoing history. See Editorial, Authority of the Accontinting Principles Board, J. Accountancy, March 1964, pp. 33-34; News Report, J. Accountancy, April 1964, pp. 9-10. The matter was compromised as stated in the text. AICPA, Disclosure of Departures from Opinions of Accounting Principles Boand (Special Bull. 1964); Special Comm. on Opinions of the Accounting Principles Board, Aicpa, Report (1965). The APB has recently published its Opinion No. 6, entitled Status of Accountino Reseancil Bulletins (1965), setting forth its conclusions as to the extent to which outstanding Bulletins should be revised or should continue in full force and effect without change.

10 "The usual short-form report consists of a representation as to the work performed, expressed in an opening or 'scope' paragraph, and a representation as to the independent auditor's conclusions usually in a closing or 'opinion' paragraph." Commmtree on Auditing Procedure, op. cit. supra note 4, at 57. The opinion paragraph usually reads substantially as follows:

"In our opinion, the accompanying balance sheet and statement(s) of income and retaincd carnings present fairly the financial position of $X$ Company at June $30, x^{-}-$, and the results of its operations for the year then ended, in conformity with generally accepted accounting principles applicd on a basis consistent with that of the preceding year." 
presented in accordance with "g.a.a.p." It appears to be implicit in the entire approach of accountancy to financial reporting that the opinion as to fairness of presentation is to be judged in the light of "g.a.a.p." As will be shown later, the accounting concept of income differs materially from any economic concept of income, and it seems obvious that the accountant's opinion as to fairness cannot be judged in the light of economic theory. However, the recent AICPA policy change makes it clear that while an official Institute pronouncement is deemed to be in accord with "g.a.a.p." it is possible that a departure therefrom (which must be disclosed) might in a specific instance more "fairly present" the company's condition and operations. What standard or criterion is to be used to judge the fairness of presentation, if "g.a.a.p." are abandoned, is not set forth.

\section{Scope of the Paper}

The purpose of this paper is to raise the question of the relationship between "g.a.a.p." as established by the accounting profession, and corporation law, as found in statutes and court decisions. Is the accounting view correct that accounting questions encountered in corporation law fall in areas of "special-purpose" accounting, toward which "g.a.a.p." are not specifically directed and by which "g.a.a.p." are in no way controlled? Or is there a closer and more intimate relationship?

Financial accounting principles have, of course, a direct relevance to corporate reporting to shareholders and the public, and the federal securities laws have assigned to the Securities and Exchange Commission a major role in supervising this phase of corporate activity. ${ }^{17}$ The SEC has thus become intimately involved with questions of accounting principle under statutes that prescribe no accounting rules and use no accounting terms but that accord a broad regulatory power over accounting practices. ${ }^{18}$ State corporation statutes, on the other hand, govern matters of internal corporate financial structure and are largely unaffected by the needs of investors and the public for financial information. Such laws typically do require corporations to keep "correct and complete" books and records of account and contain provisions

\footnotetext{
${ }^{17}$ Securities Act of 1933, $\$ 19(a), 48$ Stat. 85, 15 U.S.C. $\$ 77 s(a)$ (1964); Securities Exchange Act of $1934, \S \mathrm{I}_{3}(\mathrm{~b}), 48$ Stat. 894 , 55 U.S.C. $\$ 78 \mathrm{~m}$ (b) (1964).

${ }^{18}$ See generally Pines, The Securities and Exchange Commission and Accounting Principles, supra, pp. 727-5I. The New York Stock Exchange has also assumed certain regulatory functions over accounting practiccs of listed companies. See New York Stock Exchange, Company Manual (loose-leaf) A-20 (timely disclosure), $A-26,-94$ (charges against capital surplus), A-64 ff. (financial statements required to be independently audited), A-91-92 (changes in accounting methods), A-r2o (disclosure of stock options in annual report), A-235, $-256-57$ (accounting treatment for stock dividends and stock splits), B-4I-45 (accounting and financial policies disclosed). The Exchange also attempts to exercise influence over accounting matters simply by persuasion. It is understood, for example, that currently it is attempting to have all listed companies separate nondepreciable real estate from depreciable plant and equipment on their balance sheets, and have statements of cash flow covered by the independent accountants' reports. For the history of the development of NYSE accounting requirements, see Storey, op. cit. supra note 7, at 9-15; AIA, Audits of Corporate Accounts (I934); George O. May, Financial Accounting 4I-44, 55-56, 209 (I943); Subcommittee on Independent Audits and Audit Procedure, op. cit. sitpra note 7; Research Studi No. 7, at 7 .
} 
allowing inspection thereof or requiring the mailing of annual reports to shareholders. However, these laws give little or no guidance as to the substance of financial statements issued by the corporation beyond perhaps prescribing the statements that must be included. ${ }^{19}$

Although state corporation laws are not usually concerned as such with accounting principles to be utilized in the preparation of financial statements, accounting problems nevertheless loom large in the application of numerous of the statutory requirements. The relevance of accounting theory and practice in these areas is a matter that can be debated at great length. The ensuing discussion should demonstrate the need for more attention to the strengths and weaknesses of modern accounting in the framing and interpretation of corporation statutes.

\section{II}

\section{The Corporation Law Approach: Assets and Capital}

Unlike the federal securities laws and the SEC's efforts thereunder, the state corporation laws antedate by many years the development of modern accounting. The original approach to the financial and accounting problems encountered in corporation law was thus formulated without the benefit of more than rudimentary accounting theory. Against the background of a long history of established policies and methods of approach, modernization of the law has been difficult and at best slow.

At the outset it must be recognized that the legal approach to accounting in corporation law has stemmed not from the goal of informing existing shareholders and potential investors of the financial condition of the corporation but primarily from the double aim of (I) affording investor and creditor protection by assuring the existence of the represented capital and (2) preventing asset distributions to shareholders that would deplete such represented capital. In order to accomplish this double goal, state statutes usually provide for a comparison of assets with liabilities in order to ascertain (a) whether assets initially paid to the company for stock are equal in value to the balance-sheet capital represented by such stock in order to see whether such stock is fully paid and nonassessable, and $(b)$ whether net assets later exceed capital, and by how much, to determine whether distributions to shareholders can be made. The central core of state law pertaining to financial accounting has thus traditionally been the ascertainment and measurement of corporate net assets in relation to corporate capital as they appear on a balance sheet.

The law also values assets received upon the issuance of stock for other purposes: for example, to determine whether existing shareholders have a right to object to the issue (or have a right of first refusal) on the ground that their interests will be diluted unless "fair value" is received. Of course, asset valuations also determine

\footnotetext{
${ }^{10}$ See ABA-ALI Modes Bus. Corp. Act Ans. $\$ 46$ (1960) [hereinafter cited as Modez Acr]. Cf. id. $\$ \$$ II 8 -19, requiring reports of values for tax purposes.
} 
the basis for depreciation and amortization of fixed assets. These issues and the interrelation of the concepts of value involved will be touched on later.

With respect to subsequent dividends, distributions, and acquisitions after incorporation, the legal rules as to valuation of assets have fallen into three categories: $(x)$ a series of prohibitions based upon "insolvency," either an inability to pay debts as they mature or an insufficiency of assets to cover all liabilities; (2) a "capital impairment" rule, under which distributions may be made only when there exists a surplus of assets in excess of liabilities and capital; and (3) a "net profits" test, limiting distributions to current or accumulated net profits. Variations and combinations of these three tests have proliferated in the fifty states. Legislatures and courts, not learned in accounting, have used accounting terms in the regulatory process, and the result has been a nearly incomprehensible mixture of accounting and legal terms ranging from such phrases as "profits and surplus funds"20 to "actual legitimate net earnings."21 The law in most jurisdictions equated the "capital-impairment" and the "surplus-profits" tests, indicating that any surplus of net assets in excess of capital constituted surplus profits, and vice versa. ${ }^{22}$ The legal rule thus formulated requires a comparison of two items, each of which requires definition: first, the "value" of net assets and, second, the "legal capital" of the corporation. The necessity for defining both these terms has raised a host of problems that are at the core of financial accounting.

\section{A. The Definition of Capital}

In economics and accountancy, "capital" consists of the assets contributed by the shareholders to the enterprise; income over the life of the enterprise is then simply the excess of the assets at the termination date over the initial capital entrusted to the enterprise. In law, on the other hand, "legal capital" of a corporation is an entirely different concept. Starting with the notion that capital is a safeguard for creditors and investors required by law in return for the privilege of limited liability, the law has required that a representation as to capital in dollars-"quantum, not res $^{23}$ - be made by the corporation, and has then imposed restrictions and prohibitions against both reducing the representation as to capital and distributing assets that would leave the remaining net assets less than represented capital.

The legal definition ignores, and in fact denies, any dichotomous relationship between income and legal capital. For example, where stock is "watered" by its

\footnotetext{
${ }^{20}$ This was the common law rule, according to 2 Semaour D. Thompson, Parvate Corporations $\S 2 \mathrm{I2}$ (Ist ed. 1895). See Hackney, The Pennsylvania Business Corporation Law Amendments, I9 U. PITT. L. Rev. 51, 62 n.28 (1957).

${ }^{31}$ GA. CODE ANN. $\$ 22-713$ (1936). See Zeff, Legal Dividend Sources-A National Survey and Critique pts. I-2, 3I N.Y.C.P.A. 74I, 802 ( $196 \mathrm{I}$ ), which conveys an excellent notion of the variety found among the states.

${ }^{29}$ See Henry W. Baliantine, Corporations 574-75 \& n.74, 582-84 (rev. ed. 1946); Henry R. HatField, SuRplus AND DIVIDENDS 24 (I943); Hackney, supra note 20, at 63-64.

${ }^{33}$ Henry R. Hatfield, Surplus and Dividends 4 (I943). See Hills, op. cit. supra note 7, at 139-40.
} 
issuance in exchange for assets worth less than its stated capital, capital is immediately impaired, and earnings must fill the gap before any "surplus profits" can be recorded. ${ }^{24}$ In a jurisdiction allowing "nimble dividends," 25 the law acknowledges the existence of distributable income notwithstanding the capital impairment. In situations where legal capital may be set at a figure lower than the value of the consideration paid for the stock, the law (in the absence of specific restrictions upon paid-in or capital surplus) acknowledges the existence of "surplus profits" available for distribution notwithstanding the absence of real income.

Legal capital therefore is a highly artificial concept that has little relation to economics or accountancy, and dividend law based thereon has been severely criticized as an unworkable and incomprehensible system that rests on "vague financial standards difficult to ascertain and apply."28 It follows that accounting principles are of little help in defining or computing legal capital for the purpose of applying state corporation laws. ${ }^{27}$

The authorities are divided over whether the amount of legal capital must or ought to be shown in published financial statements. ${ }^{28}$ The more important fact, however, is whether or not and on what conditions dividends can be paid, and, so long as any restriction upon the availability of earned surplus for dividends is shown, it no longer appears that legal or stated capital is a figure of sufficient significance that it must appear as such on the balance sheet.

\footnotetext{
${ }^{21}$ By contrast, proper accounting requires deducting the amount of the discount from the capital account, thereby making it improper to amortize the discount against future revenues; all subsequent earnings are therefore carried out by the accountant to earned surplus. See SEC Reg. S-X, rule 3.I\%, I7 C.F.R. \$210.3-I7 (1964); Robert H. Montgomery, Auditing 424 (8th ed. 1957); William A. Paton \& William A. Paton, Jr., Corporation Accounts and Statements 55-59 (r955).

${ }^{25}$ E.g., Del. Code Ann. tit. 8, \$ I70 (I953). See Ralph J. Baker \& William L. Cary, ConporaTIONS I228-34 (3d ed. 1959).

${ }^{20}$ Henry W. Ballantine, Corporations 588 (rev. ed. 1946).

27 The Pennsylvania Business Corporation Law follows the accounting approach of aggregating the total shareholder contributions (stated capital and capital surplus) and defines earned surplus in effect as increment of net assets in excess thereof. PA. Srat. ANN. tit. 15, \$2852-2 (Supp. 1964). The Model Act approach, on the other hand, is to take total assets and deduct first legal capital and then carned surplus in order to determine capital surplus. MODEL Acr \$2. See Garrett, Capital and Strrplus Under the New Corporation Statutes, 23 LAw \& ConTEMP. PRoB. 239, 259 (1958); Hackncy, stipra note 20, at 69-70. The difference, however, may be largely one of semantics; except for the narrow question of permissible charges against capital surplus, the important question in either case, as will be seen, is the valuation of assets.

${ }^{38}$ ReseARCh Bull. No. 12 (I94I) suggested that designations in the stockholder equity section $\mathrm{cm}$ phasize the distinction between legal capital and other capital. Resenrch BuLl. No. 39 (r949) recommended the discontinuance of certain legal terminology and stated that "consideration should be given primarily to the sources from which the proprietary capital was derived." ResEARch STUdY No. 3 reflects the confusion in accounting thought: Invested capital is defined as stockholders' equity arising from contributed assets or capitalization of earnings "which will not be withdrawn or reduced except as permitted by law" (id. at 9 ), but then states that financial statements are "primarily economic rather than legal documents" and therefore an accounting "which reflects the basic economic distinctions is paramount." Id. at $4 \mathrm{r}$. A common method among accountants of reporting capital stock is to carry out the par value of outstanding shares, net of treasury stock (leaving surplus untouched) [sec AICPA, Accounting Trends and Technioues $133-37$ ( 17 th ed. 1963 )], while under most state laws legal capital is not reduced by purchase of treasury stock (but surplus is).
} 
B. The Question of Asset Valuation in the Determination of Income

By far the more difficult and confusing aspect of the relationship between law and accounting is the question of asset valuation.

The common denominator of most basic dividend, distribution, and liquidation rules in state corporation laws has, at least until recently, been the idea of protection in liquidation: in the event of financial difficulty, stockholders should not receive corporate assets leaving creditors unpaid, and common stockholders should not receive assets until preferred stockholders have been paid the amount of their contractual preference. The idea was first strongly formulated in the "trust fund" doctrine enunciated by Mr. Justice Story in the famous case of Wood v. Dummer. The "trust fund" metaphor, implying that "capital," being a pledge or trust fund for the payment of corporate debts, is an asset, has undoubtedly been the cause of much confusion in the law. ${ }^{30}$ Nevertheless, the following basic reasoning used by Mr. Justice Story was felt to be fundamentally sound and was the basis for much of the ensuing dividend law for over a century:

The charter relieves [the stockholders] ... from personal responsibility, and substitutes the capital stock in its stead. . . . Why, otherwise, is any capital stock required by our charters? If the stock may, the next day after it is paid in, be withdrawn by the stockholders without payment of the debts of the corporation, why is its amount so studiously provided for, and its payment by the stockholders so diligently required? ${ }^{31}$

The objective of the trust fund doctrine was expressed by the rule that dividends could not be paid out of capital but only out of profits. As previously shown, it was implicitly assumed in all the legal formulations that the two tests were identical: if there were no profits, then of necessity a distribution would be out of capital (or would "impair" capital), and vice versa. ${ }^{32}$ From this it appeared in law that a surplus of net assets indicated the existence of net profits: "Surplus' or 'profits' denote an excess in the aggregate value of all assets of a corporation over the sum of its entire liabilities, including capital stock. ..."33

Once the benchmark of legal capital is defined, it can easily be seen that the fundamental question is the valuation of the assets in question in order to see whether they exceed the quantum so set. The fundamental issue, then, is this: in applying any given legal rule-whether it be a question of watered stock, or capital impair-

${ }^{20} 30$ Fed. Cas. $435,436-37$ (No. 17944 ) (C.C.D. Me. 1824).

80 The inaptness of the metaphor was ignored, "perhaps from the traditional disinclination of the chancellors to respect, perhaps even to understand, the meaning or effect of accounting matters." Gibson, Surplus, So What?, I7 Bus. LAw. 476, 485 (I962). It was stated some years ago that "the basic idea expressed in the opinion-that the investment of the stockholder shall be retained intact in the enterprise as a margin of safety for creditors-has now been codified in some form in the corporation laws of virtually every state." Comment, 49 YALE L.J. 492, 495 (1940) (footnotes omitted).

31 Wood v. Dummer, 30 Fed. Cas. 435,436 (No. I7944) (C.C.D. Me. I824).

${ }^{82}$ See note 22 supra.

${ }^{33}$ Branch v. Kaiser, 29 I Pa. 543, 549, r40 Atl. 498, 500 (1928). 
ment, or the existence of a surplus, or earned surplus, or income ${ }^{34}$-to what extent will the law look to "g.a.a.p." in the valuation of assets?

"Value" is a word of many meanings, depending largely on context; economists cannot agree on concepts, nor can accountants, and it is clear that the word has a chameleon-like quality as well in American judicial decisions. Valuation in personal injury suits, for condemnation purposes, for insurance policy claims, for property tax purposes, for determining "solvency" for purposes of bankruptcy or fraudulenttransfer statutes, for estate and inheritance tax purposes, for realignment of investors' interests in corporate reorganizations, for interpreting private contracts, and so on indefinitely-valuation principles for all these different legal purposes involve different concepts of value. ${ }^{35}$

One entire category of valuation principles is that made for the purpose of computing income. Here again the concept of valuation to be adopted will likely be subject to many variations dependent upon the purpose for which income is to be determined. For example, the measurement of taxes based on income or on "excess profits," the redetermination of "fair profit" on certain government contracts, the determination of rates to be charged by public utilities, the apportioning of corporate distributions between life beneficiaries and remaindermen, the determination of the legality of securities as investments for institutional investors, the making of payments of interest on income bonds or rent under percentage lease contracts, the determination of income under profit-sharing plans, compliance with restrictions in indentures, charters, and other contracts-again, with an infinite variety-all illustrate how the purpose of the computation of income dictates the method of valuation to be followed.

It is significant that the concepts of "value" in virtually all the usages stated above other than the computation of income are aimed at an attempt to determine worth (e.g., of what is to be acquired or what was damaged or lost or taken) in some significant manner. It is becoming more and more widely understood, however, that accounting "valuations" that are made in accordance with "g.a.a.p." for the

\footnotetext{
${ }^{84}$ The question of asset valuation is equally at the core of an income or earned-surplus test as it is fundamental to a surplus or capital-impairment test. From the nature of double-entry bookkecping, the accounting balance sheet and income statement are so articulated that accounting principles followed in determining income have a direct effect on balance-sheet assets and liabilities (and therefore surplus), and, conversely, accounting principles followed in preparing the balance-sheet valuations for assets, reserves, and liabilities will be reflected in the income statement (or, to a limited degree, directly in surplus). See Robert H. Montgomers, Auditing 426 (7th ed. 1949):

"Whatever principles of valuation are applied to current assets, whatever policies are adopted in the capitalization and depreciation of plant, and whatever the methods of recognition of liabilities, all find their way to income or, to a limited degree, directly to surplus. Appreciation of this relationship has more and more led accountants to apply accounting principles so as to result in the fairest determination of income with only secondary consideration of the balance sheet result, and thus the position of relative importance may be reversed."

Thus the real question in either case is not one of computation but of interpretation: what concept of valuation of assets is at the root of state corporation laws?

${ }^{35}$ See James C. Bonbright, The Valuation of Propertix (I937).
} 
purpose of determining "business income" are not aimed at determining "worth" in any significant sense. ${ }^{36}$

\section{III}

\section{Accounting Valuation Principles}

In the first decades of this century, accounting concepts of income and the objectives of the dividend statutes appeared to be generally in accord with each other and with the view that a balance sheet was intended to show the worth-value of assets compared with liabilities and that all increase in such net worth was deemed "profits."37

During the rg20s-a period of considerable price inflation, following a long period with no serious over-all deflation-revaluations of fixed assets became frequent, justified largely on the grounds (I) that under then current conditions balance-sheet assets stated at invested cost were so undervalued that they could no longer fairly present the company's financial position and (2) that new values were needed in order to provide a basis for computing depreciation expense and amortization necessary for competitive pricing decisions. ${ }^{38}$ The desire of the utility industry to recover replacement costs from rates charged to customers, the perhaps gratuitous interpretation of the sixteenth amendment as allowing all pre-Igr 3 unrealized appreciation in value to escape taxation as pre-I9I3 "income," and the economic "going-concern" theory that basic productive capacity must be maintained before any income could be shown all combined to allow current "worth" valuation of assets to be reflected in balance sheets for accounting purposes.

The great depression resulted in a violent reaction against admitting to the balance sheet any valuations in excess of historical cost. More and more the accounting notion of income came to insist that periodic income consists of excess of receipts earned or accrued over an allocable portion of costs spent or accrued, so that income has come to represent accrued receipts less allocable costs, rather than an increase in net worth. ${ }^{39}$

The change in emphasis ${ }^{40}$ and approach has resulted in a radical shift in the

\footnotetext{
${ }^{30}$ For an excellent discussion and analysis of accounting principles of valuation in a legal context, see De Capriles, Modern Financial Accounting, 37 N.Y.U.L. REv. roor (rg62) (pt. I), 38 id. I (rg63) (pt. 2).

${ }^{37}$ See Study Group on Business Income, Changing Concepts of Business Income 21, 23-25, 27-28 (I952); George O. MAx, Financial Accounting 5, 8, 37-39, 79-80, 90-95 (I943); Littleton \& ZimamerMaN, op. cit. supra note II, at 154; Terninology Bull. No. I, at I6-I7.

${ }^{88}$ See LitTLEton \& Zimmerman, op. cit. supra note iI, at 97.

${ }^{30}$ See authorities cited in note 37 supra. See also 2 James C. Bongright, The Valuation of Property 902-06, 9io-il (I937); Raymond P. Marple, Toward a Basic Accounting Philosophy I03-I7 (I964); ReseARCH Study No. 7 at, 4I-42; Storey, op. cit. supra note 7 , at 44-45.

${ }^{\circ}$ The AICPA in 1938 adopted the view that "a fair determination of income for successive accounting periods is the most important single purpose of the general accounting reports of a corporation." Study Group on Business Income, Changing Concepts of Business Income ig (r952). Since I900, "perhaps the most significant [accounting] change of all is the shift of emphasis from the balance sheet to the income account, and particularly to the income account as a guide to earning
} 
method of valuation of assets for balance-sheet purposes, so that book values no longer represent or have any necessary relationship to worth-values. An examination of several accounting principles or postulates ${ }^{41}$ fundamental to the accounting concept of income will be helpful to the lawyer in assessing the relationship between accounting methods of valuation and legal notions of surplus or profits.

\section{A. Assets as Unexpired Costs}

Over the life of an enterprise, according to the accounting approach, the aggregate net income may well be the same as the economic notion of an increase in value of net assets; but the important-and difficult-function of accounting is to allocate net income in a useful manner to arbitrary short fiscal periods. In making such allocation, accounting theory states that current expensing of all current outlays-for example, for fixed assets such as land, plant, and equipment-would distort the periodic net income for the years in question by charging too much to the current year and not enough to future years. The same approach is made to inventories and supplies, costs of which are carried forward to be matched against the revenue of the year of sale rather than the year of purchase. The deciding factor is often whether an expenditure has expired in usefulness, necessarily often a question of judgment, which it would be impossible to apply to every single debit entry over a year's time for any sizable enterprise. Accounting conventions (arbitrary assumptions) fill the gap, aimed not at ascribing any worth-value of properties remaining on hand but at properly allocating costs and expenses (and resulting income) between current and future years. Thus, for example, a replacement of a tool expected to last several years may be capitalized, while a paint job expected to last for five years may be expensed as a repair item; and current labor expense going into the conversion of raw materials into work-in-process will be "capitalized" (carried forward as an asset) so as to be charged against the year of sale, while no

capacity rather than as an indication of accretions to disposable income." Grorge O. MAY, Financias Accounting 5 (x943). See also Research Bulletin No. 43, at 7; Robert H. Montgomery, Auditino 434 (8th ed. 1957 ); W. A. Paton \& A. C. Litrleton, An Introduction to Corporate Accountino Standards 66-67 (1940); Study Group on Business InCOME, op. cit. stipra, 59-60, 120.

${ }^{11}$ A peculiar aspect of the current turmoil in the accounting profession over proper accounting is the controversy over terminology. Stephen Gilman found in 1939 that four terms-convention, rale, doctrine, and principle-were used almost interchangeably in practice; and attempting to differentiate between them, he found three accounting conventions, four accounting doctrines, a number of accounting rules, and no accounting principles. Accounting Concepts of ProfIT chs. I2-I6 (1939). See also STOREY, op. cit. supra note 7, at 2x-24. George O. May popularized the use of the term "postulate" as an underlying accounting convention [e.g., Financial Accounting ch. III (1943)], while the AAA set forth "standards" or "fundamental axioms" against which accounting practices and procedures might be judged. The uses of all these terms in the recent Accounting Research Studies seem to depend largely upon who is writing. See Maurice Moonitz, The Basic Postulates of Accounting (AICPA Accounting Research Study No. $\mathrm{r}$, r96r) [hereinafter cited as Research Study No. I]; Research Study No. 3. Cf. Research Study No. 7, ch. 2; Arthur Andersen \& Co., The Postulate of Accounting (1960); STOREY, op. cit. supra note 7, at 6I-62. It appears to a layman that the important thing is not whether, for example, the "cost basis" is a principle or practice or whether the stability of the dollar should or should not be called a "postulate" of accounting but rather to delineate the primary objective of accounting and the underlying concept of income that financial statements should seek to reflect. 
amount of objective evidence as to actual value of self-developed goodwill will validate the capitalization of expenses contributing thereto.

Expenditures, then, that according to accounting convention are deemed to contribute to the production of revenue in a future year or years-whether they were incurred for the purchase or processing of inventories held at the end of the year for future sale, or for the rendition of services over future years, or for the acquisition of fixed or intangible properties forming "enterprise service capacity" still available at the end of the year to produce future enterprise revenue-are capitalized and therefore deemed "assets" on the accounting balance sheet. Disregarding the idea of increase or decrease in realizable or other economic worth at a particular time, the accounting or "prorated-revenues-and-expenses" approach to valuation thus looks upon the statement of assets as essentially a statement of residuals or unexpired costs "representing a pool of waiting productive potential"-no more and no less than those prior outlays or expenses that were not previously charged against the revenues of prior periods and remain available to contribute in some measure to future productive or financial activities. ${ }^{42}$ Fixing the book value of corporate assets under this approach involves a process that cannot be construed even as a serious attempt to measure values in any economic or worth-value sense but is essentially a matter of carrying forward unexpired costs. This is one of the chief reasons why it is commonly recognized that modern principles of accounting for income result in a "distortion" of the balance sheet-i.e., a failure to approximate economic values.

\section{B. The "Going-Concern" or Continuity Postulate}

Accountancy argues that the assumption may logically be made that the enterprise may be expected to continue indefinitely in existence and that therefore random changes in market or replacement values of assets devoted to productive use are irrelevant in the computation of income. The postulate is basic to the notion described above of assets as unexpired costs, and implies a number of other arbitrary but far-reaching assumptions made in accounting that result in balance-sheet "values" differing from current fair market or realizable value." As examples, the following may be cited:

(a) Unless there is indication of an involuntary interruption of operations, such as insolvency or bankruptcy, forced-sale or involuntary liquidation values are irrelevant to balance-sheet valuations.

\footnotetext{
12 Terminology Bull. No. I, at 13; Research Study No. 7, at 225; AAA, Accounting AND Reporting Standards for Corporate Financiat Statements \& Preceding Statements \& Supplements 3-5 (1957); LITILETON \& ZMMMERMAN, op. cit. supra note II, at 146-48, 167-68. See generally Graham, Some Observations on the Nature of Income, Generally Accepted Accounting Principles, and Financial Reporting, supra, at pp. 652-73, at 66I-64.

"See generally Resenrch Bulz. No. 43, at 59; Research Study No. I, at 38-4I; Research Study No. 7 , at 27-30; Study Group on Business Income, Changing Concepts of Business Income 22-23 (1952); AAA, op. cit. supra note 42 , at 2 .
} 
(b) The going-concern postulate will frequently yield as an accounting "asset" an expenditure of prior years that may have little or no realization value. Thus, for example, an advertising or promotional outlay made in one year may result in no property right in a legal sense, but accounting convention holds it is improper to charge it off in the year of expenditure because it was made with the expectation of its being a nonrecurring item that will benefit operations for an indefinite term, or at least more than one year, in the future.

(c) In valuing work in process, the amount of labor and other production costs ("product costs") as well as allocable portions of maintenance and depreciation and other overhead factors ("period costs") are added to material costs in the expectation that the work in process will be finished and sold, although the immediate market value of work in process may be lower even than the market value of the materials before processing.

(d) The going-concern postulate allows a receivable to be entered as an asset and valued and recognized as income according to the size of the anticipated future cash receipts, not the present realizable (liquidation) value of the receivable in the market based on the period of expected delay in payment, and notwithstanding that there may be some legal aspect of the transaction that presently bars the right to sue and obtain immediate judgment.

(e) The assumption of continuity justifies carrying forward on the balance sheet such deferred assets as organization and promotional outlays, debt discount and expense, research and development costs, and other unexpired costs that may have little or no exchange value but which the proper matching of revenues and costs requires to be carried forward to be charged against future revenues.

(f) On the assumption that the enterprise will endure longer than any separate assets that are included in accounting for it, the going-concern concept requires an arbitrary assumption of the using-up of the services supplied by these assets rather than their sale in the market place or their replacement. Therefore random changes in market or replacement values of depreciable assets are ignored, and depreciation is justified essentially as a systematic amortization or distribution of cost over expected life, rather than as a decline in observable, realizable replacement or other use-value. Depreciation in accounting is thus to be sharply distinguished from the sense of "fall in value" in which the word may be employed in common usage." "It is a process of allocation, not of valuation," ${ }^{45}$ a "periodic amortization of a prior investment made to indicate the gradual conversion of that prior investment into periodic revenue charges." ${ }^{\text {}}$

\footnotetext{
14 "The word depreciation is an outstanding example of a term used in accounting in specialized senses. The sense in which accountants use this term differs not only from its colloquial sense but also from the sense in which it is used in engineering; and it is far removed from the root-meaning (diminution in price or value) of the word itself." Terminology Bulz. No. $x$, at 20.

Id. at 25 .

${ }^{46}$ Litilleton \& Zimimerman, op. cit. sitpra note $\mathrm{II}$, at $\mathrm{x} 59$.
} 


\section{The Realization Postulate}

The insistence upon the cost principle and the refusal to recognize as income increases in values until realized by sale or use stem largely from the realization postulate, one of the fundamental accounting conventions. The requirement of realization, perhaps originally stemming from nineteenth century economic thought, ${ }^{47}$ became dominant again after the period of the I920s with the decline among accounting authorities of the "increase-in-net-worth" concept of income. The result is that ordinarily no new values in addition to cost (or original fair value) can be introduced, prior to realization, into the balance sheet; the book value of an asset is thus clearly seen as being merely that portion of original exchange value not previously charged to revenues-"a by-product of the realization rule, as applied to the determination of profit, and not of an independent determination of the asset itself." ${ }^{48}$

We have seen that in accounting, depreciation is a process of allocation of cost of fixed assets, not of valuation. Likewise, all increase in value of fixed assets, whether arising from market fluctuations, shortages, changes in surroundings, or otherwise, is said to have nothing to do with allocation of cost and is therefore irrelevant to computation of accounting profit unless realized by sale or conversion. The accountant's regular charge to each year's profit-and-loss account of a constant or other systematic proportion of original cost, regardless of possible current worth-value equal to or in excess of cost, will result in a balance-sheet pseudo-valuation consisting simply of unamortized cost and bearing only a fortuitous relationship, if any, to worth-value. While accountants assert that write-downs below depreciated cost may and perhaps should be made where there is a decline in value due to a permanent fall in income-producing capacity, American accounting has not in the last three decades countenanced the recording of appreciation in fixed assets on the books. ${ }^{49}$

Inventory valuation principles also demonstrate a refusal to anticipate values created prior to realization. While accounting recognizes that profit is attributable to the over-all process of production and not just to the moment of sale or delivery, its principles dictate that ordinarily profit is recognized and enters the accounts only at the moment of sale. ${ }^{50}$ The basic accounting principle appears to be that

\footnotetext{
${ }^{47}$ See id. at $87-88,90$.

4 Research Study No. 3, at 16 . See also AAA, op. cit. supra note 42, at 3-4: "Any increase or decrease in the aggregate amount of assets should be corroborated by a market transaction or its equivalent. . . . In all cases the requirements of objective measurement should be met; the concept of realization provides general standards for the recognition of asset increases."

${ }^{10}$ Researce Study No. 7, at 44, 56; Rappaport, op. cit. supra note 4, at 3.9-.I6 See Harvard Business School Accounting Round Table, The Measurement of Property, Plant, and Equipanent in Financial Statements 6-7 ( 1964$)$; Henry R. Hatfield, Thomas H. Sanders \& Norman L. Burton, Accounting Princtples and Practices 344-5I (I940); George O. May, Financial Accounting 90-95 (rg43).

${ }^{\circ 0}$ In a much-quoted passage, George 0 . May explained the attribution of income to the moment of sale
} 
where goods are held for sale in the ordinary course, so that an actual future exchange value, unknown at present, will ultimately be recorded to measure income, it is usually wrong to attempt to anticipate the ultimate sales price by taking up any revenue (whether "production" gain or "holding" gain) from increased value (other than cost) prior to sale. Accounting not only fails to recognize "holding" income in the year in which such gain occurs, but has been vigorously criticized for its failure even in the year of realization to distinguish at all between holding gain and profit from production or use. ${ }^{51}$ The attempt through LIFO inventory valuation to charge current inventory costs to current periods would seem to result in indefinite deferral of holding gain while resulting balance-sheet values become further and further removed from current worth-values.

\section{The Monetary Postulate}

The monetary postulate, one of the longest established but today one of the most controversial of all accounting conventions, states that fluctuations in value of the monetary unit, the accounting unit of measurement, may properly be ignored. ${ }^{62}$ The result is that the money gain resulting from holding assets in a period of inflation (loss in the value of money) is not segregated or reported at all in the period prior to realization but is then reported as operating income. The result occurs not only

as a purely conventional treatment, "justified only by its demonstrated practical utility," and pointed out how in some instances the convention lacks validity. Financial Accounting 30-31 (1943). Sprouse \& Moonitz, in commenting on May's text, quote Paton to the effect that "there is general agreement in accounting ... that revenue results from the over-all process of production" (Paton, "Deferred Income"-A Misnomer, J. Accountancy, Sept. I961, p. 38, at 39), and conclude that the realization postulate is in reality a "statistical generalization" which can be applied or not, depending on whether it fits the situation under review. RESEARCK STUDY No. 3, at ro-I4. In a few instances only, such as valuation of inventories of precious metals or agricultural products and by-products of all types (sce RESEArcr BuLl. No. 43, at 34; RESEARCH Study No. 3, at 27), or in accounting for carrying out long-tcrm construction contracts [sce Research Bull. No. 45 (1955); Herwitz, Accounting for Long-Term Construction Contracts: A Lawyer's Approach, 70 HARv. L. REv. 449 (1957)], accounting principles allow the recognition as income of unrealized appreciation in value of inventories or work in process. In other instances, not involving revaluation of assets, such as accrual of interest receivable, income is deemed "earned" before it is "realized." See Henry R. Hatrield, Surplus and Dividends 42 (1943).

${ }^{81}$ See, e.g., Edgar O. Edwards \& Phillip W. Bell, The Theory and Measurement of Business INCOME 9-12 (I96r). Sprouse and Moonitz propose to distinguish among three types of incomethe amount attributable to price-level changes, holding profit, and operating profit-and conclude that "any realization rule that is rigorously applied involves the risk of reporting the wrong amount of profit in the wrong period as specific prices change, and of reporting capital restatements as profit or loss when the general price-level changes." Research Study No. 3, at 77 . The authors would show changes in the value of both fixed assets and inventories (in excess of general changes in the price level) in income for the year, but reported separately from profit arising from normal operations. See id., ch. 2. The APB, however, felt that the Study contained "inferences and recommendations in part of a speculative and tentative nature" and that the recommendations "are too radically different from present generally accepted accounting principles for acceptance at this time." News Report, J. Accountancy, May 1962, pp. 9-10.

82 "The generally accepted accounting concept of income results from matching money revenues with the money costs incurred to produce them." Editorial, J. Accountancy, July I960, p. 25 (cmphasis added). See AAA, op. cit. supra note 42, at 2-3; EDwards \& BELL, op. cit. supro note 5I, at 9-Io; Study Group on Business Income, Changing Concepts of Business Income 20 (1952); RESEARCF STUdY No. 7, ch. 9. 
with respect to inventory held through a period of rising prices but also indirectly with respect to fixed assets as exhaustion charges continue to be based on historic costs, so that in both respects money gain arising from devaluation of the dollar is reported as operating profit: on inventory, in the period of sale, and on fixed assets, throughout their life, in the amount by which book depreciation is less than economic exhaustion.

The "money illusion" has been probably the most troublesome problem to confront accountants in recent years, and the criticism of the failure of accounting principles to recognize it has been extensive. ${ }^{53}$ In a period of high replacement costs, it is easy to confuse attempts to adjust financial statements for price-level changes with a system of accounting that would strive to reflect the economic concept of income through exhaustion charges based on replacement cost and inventory costing on a NIFO (next-in-first-out) basis. It seems clear that mere adjustment for changes in the value of money is completely in accord with both the cost principle and the realization postulate, in that "cost" and related exhaustion charges would simply be reported in terms of current dollar values rather than historic money costs of varying dollar values taken at different times. ${ }^{54}$

A number of devices have been approved in attempting to make the income statement more meaningful in this inflationary period, such as IIFO inventory pricing, accelerated depreciation, and the like. All, however, have to date been within the framework of the historic cost and realization principles. It will be seen that efforts to increase asset-expiration charges in current periods, coupled with a dogmatic refusal to depart from the historic cost basis, result inevitably in lowering

\footnotetext{
${ }^{50}$ E.g., Robert H. Montgomery, Auditing at iv ( 7 th ed. 1949) ("One of the basic assumptions of accounting is the stability of the dollar. It just isn't sol"); PAton \& PAton, op. cit. supra note 24, at 527 ("An acceptance of the assumption that the monetary unit is stable . . . under present conditions amounts to sticking one"s head in the sand"); Henry W. Sweenex, Stabilized Accounting at xi (1936) ("The truthfulness of accounting depends largely upon the truthfulness of the dollar-and the dollar is a liar!"). See also Storex, op. cit. supra note 7, at 6. The APB has resolved that "the assumption in accounting that fluctuations in the value of the dollar may be ignored is unrealistic" (quoted in Resenrch Study No. 7, at 367), and its implied recognition of the necessity for price-level adjustments has been called "the greatest forward step ever taken in accounting." Research Study No. 3, at 74 (comments of Paul Grady). Staff of Accounting Research Div., AICPA, Reporting the Financial Effects of Price-Levej Changes (Accounting Research Study No. 6, 1963), concluded that the effects of price-level changes should be disclosed as a supplement to the conventional statements (id. at $\mathrm{xi}$ ), but the prohibition against price-level adjustments in the statements themselves, originally established in 1947 (see Research BuLL. No. 43, ch. 9A), was recently reaffirmed in APB, Status of Accounting ResenRch Bulletins (Opinion No. 6, I965). The SEC has adamantly maintained the same position. See Rappaport, op. cit. supra note 4, at 3.13-.16. The Study Group on Business Income concluded as follows in its chapter on legal considerations: "[I]t may be well to bear in mind that, if and when the question is ever presented to the courts, they may, with the benefit of hindsight, particularly if the purchasing power of the dollar continues to decline, inquire whether accountants were justified in clinging to accounting conventions adopted in the past during periods of relative price stability." Changing Concepts of Business Income 99 (1952).

* See the discussion between Carman Blough and Leonard Spacek: Blough, Accounting and Auditing Problems, J. Accountancy, July 1958, p. 78; Spacek, Can We Define Generally Accepted Accounting Principles?, J. Accountancy, Dec. I958, p. 40; Blough, Accounting and Auditing Problems, J. Accountancy, Dec. 1958, p. 73 .
} 
the balance-sheet valuation of unexpired costs, thus compounding the spread between worth-values and balance-sheet residuals.

\section{E. The Accounting Concept of Income: Accountability for Original Values}

The historic cost principle, as previously indicated, is one of the most widely accepted of accounting principles, yet is frequently misinterpreted and actually seems to be a misnomer for the principle it represents. ${ }^{65}$ Actually, accounting theory maintains that original costs (or values) are not always and without exception to be adhered to, but that new values may properly be entered when historic costs "are no longer significant measurements of the accountability of the corporation for those assets."56 In practice, however, historical acquisition costs remain the only valuation basis used. ${ }^{57}$

It would, of course, be possible for exhaustion charges always to be based on current values without doing violence to the realization postulate prohibiting the recognition of increases in value for income purposes. The real question is whether the ultimate objective in the determination of reported income is to be primarily one of maintenance of economic capital-testing the income-producing ability of management by charging it with full provision for the fair value of the amount of consumption of its income-producing tools-or one of stewardship-testing the achievement of management in terms of accomplishment with what was historically entrusted to it. Economic theory would urge that basic enterprise productive capacity be maintained before any net receipts or increase in values could be deemed to constitute income, with the result that exhaustion charges would equal the current value of the actual physical loss occasioned by wear, tear, obsolescence, and so forth, which would have to be made good before there could be any net income. There has

\footnotetext{
${ }^{60}$ The principle, more accurately stated, is that original value is the basis of accountability to the enterprise; cost is merely the best evidence of such value in the great majority of instances. See Research Study No. 3, at 25-27; Research Bull. No. 48, at 24. "Cost" is not simply a matter of proper and accurate recording of facts, but requires difficult and judgmatic decisions as to what costs are the relevant costs (e.g., allocable overhead and interest during period of construction). Sce Resenrck Study No. 7, at 254-55; Study Group on Business Income, Changing Concepts of Business Income 28-33; William A. Paton \& William A. Paton, JR., Asset Accounting chs. IX, X (I952); George O. May, Financial Accounting ch. VI (1943).

${ }^{50}$ The quotation is from May, Postulates of Income Accounting, $86 \mathrm{~J}$. Accounrancy 107, 109 (1948). A number of accounting authorities (Dickinson, Kester, Montgomery) are said to have made "cautiously vague remarks" that indicate possible approval of revaluing fixed assets to a prescnt-value basis. Hatfield, SANDeRs \& BuRTon, op. cit. stupra note 49 , at 347 .

"T See authorities cited in notes 49 and 53 supra. Grady states that fixed assets should be carried at "cost of acquisition or construction in the historical accounts, unless such cost is no longer meaningful," but the only example he gives is a write-down, not a write-up. Research Stody No. 7, at 252-53. AAA, op. cit. supra note 42 , at 6 , takes the position that "ideally" the objectives of accounting for inventories should be to "report in current terms" the cost of products and services transferred to customers and also to "report in current terms" the costs present in inventories at the end of the period (as well as to identify the gains or losses resulting from price changes). But the ideal is quickly lost sight of, since the "aim of all measurement of assets is to state the amount of available service potential in the most objective and realistic terms" (id. at 5), and the "concept of realization provides general standards for the recognition of asset increases." Id. at 4 .
} 
been in the official pronouncements of the SEC and the professional accounting associations an astonishing lack of agreement on or even discussion of the nature of income to serve as a guide in the choice of accounting practices or principles; ${ }^{58}$ but the entire preceding discussion of the development of accounting principles as they exist today indicates that accountancy has in practice chosen the stewardship approach of accountability for historic costs; in other words, the fundamental principle involved is that income is properly conceived of as a matter of accountability for money values of assets originally entrusted to management or committed to the enterprise. .9 $^{\text {. }}$

Accountancy justifies its approach by arguing that it is primarily concerned with historical description ${ }^{60}$ and that accounting is not a process of constant revaluation but a matter of taking original values and deciding what subsequent historic events will be recognized for accounting purposes. In accountancy the events to be reported-the raw materials of accounting-consist essentially of exchange transactions. ${ }^{61}$ Substantially all charges (both expenses and assets) are therefore to be

${ }^{58}$ George O. May stated in 1943 that "the present ferment in accounting thought is very largely due to conflicting objectives of those who would continue to regard financial statements as reports of progress or of stewardship, and those who would treat them as being in the nature of propectuses." Financial Accountivg 21 (1943). There is, however, very little diseussion of the philosophy of accounting in these terms. Paul Grady, former Director of Accounting Research of the AICPA, recognized that "the identification and description of generally accepted accounting principles necessarily embraces more than the professional work of certified public accountants and must reach back to the primary steps by which management meets its accountabilities to investors and others having legitimate interests in the business cnterprise." Grady, The Quest for Accounting Principles, J. Accountancy May, 1962, p. 45, at 46. Leonard Spacek's view is that "one basic accounting postulate underlying accounting principles may be stated as that of fairness-fairness to all segments of the business community (management, labor, stockholders, creditors, customers and the public), determined and measured in the light of the economic and political environment and the modes of thought and customs of all segments-to the end that the accounting principles based upon this postulate shall produce financial accounting for the lawfully established economic rights and interests that is fair to all segments." Researck STUdY No. I, at 57 (comments of Lconard Spacek). Grady's position was criticized as "essentially a defense of the status quo" [ResenRch Study No. 3, at 65 (comments of Arthur M. Cannon)], while Spacek's objective was called "not satisfactory ... as a point of departure for an objective inquiry [into the basic postulates of accounting]." RESEARCH STUDY No. I, at 4. Neither position comes to grips with the essential question stated in the text.

${ }^{50}$ Spacek, for example, criticizes currently accepted principles of accounting for goodwill as implying that the income statement is "a statement of venture results," while he urges that the profession look to the income statement "to show us the results of operations of a company's producing assets." Spacek, The Treatment of Goodivill in the Corporate Balance Sheet, J. Accountancy, Feb. 1964, p. 35, at 39. The difference in approach is exemplified by Blough's assertion that the accounting concept of depreciation has nothing to do with financing the replacement of assets or maintaining the productive capacity of plant and equipment (J. Accountancy, July 1958, pp. 78-79), while Spacek argues that there can be no income until original capital has been returned in terms of today's purchasing power. Spacek, Can We Define Generally Accepted Accounting Principles?, J. Accountancy, Dec. 1958, p. 40, at 44.

${ }^{\circ 0}$ SEC Accounting Ser. Release No. 53, Nov. 15, 1945, II Fed. Reg. I0912 (1946); Edwards \& BELL, op. cit. supra note $5 \mathrm{I}$, at I ("Economics deals with the future and the decisions which will determine that future, while accounting is primarily concerned with historical description."); id. at 5; George O. Max, Financial accounting 22 (I943); Marple, op. cit. supra note 39, at ix3-16.

o1 Researci Study No. I, at 10; AAA, op. cit. supra note 42, at 3:

"The essential meaning of realization is that a change in an asset or liability has become sufficiently

definite and objective to warrant recognition in the accounts. This recognition may rest on an 
based on actual past transactions, while all credits to profit and loss are to await realization and be based on a consummated sale following delivery or performance of service.

The surprising thing is that the stewardship approach to the determination of income is recognized to be better suited to reflect profitability for an original owner than for a recent investor, and to be comparatively inapt as a means of projecting future profits (and therefore present value) ${ }^{62}$ yet the prime objective of public accounting today is to serve the recent investor and the potential investor in the large publicly held companies having listed or widely traded securities and in the company making a public offering of its securities.

There has, nevertheless, been dissatisfaction within accounting circles with the limitations of the stewardship concept, resulting in increasing attempts to recognize current values in recording revenues and to charge current receipts with costs adjusted for changes in the price level or else with the best possible approximation of current values; ${ }^{63}$ but so long as total charges are limited to aggregate historic cost totals, it is obvious that the more costs that are charged off currently to income, the fewer are the costs that remain to be carried forward as assets to be charged against income of future years. As yet nothing official has developed within the accounting profession that would allow the balance sheet (or bases for exhaustion charges) more closely to approximate price-level-adjusted cost or replacement cost.

\section{F. In Summary}

Fundamental and generally accepted accounting conventions or principles demand that asset valuation on a balance sheet be not an attempt to state a current worth-value but rather be essentially a matter of carrying forward a residue figure consisting of unexpired historic costs. It has been shown that this "useful cost" figure may be higher than actual current exchange or forced-sale value in some instances, such as work in process and deferred charges; will in an inflationary period usually be lower than current exchange value, as in the case of inventories carried on a LIFO basis or fixed assets that have appreciated in value or that have been depreciated on an accelerated basis; and will in most events be based upon original value (usually historic cost) without regard to decline in value of money

exchange transaction between independent parties, or on established trade practices, or on the terms of a contract performance of which is considered to be virtually certain . . . .

-...

"Typically, the initial appearance of an asset within an entity is the result of an exchange transaction ...."

${ }^{62}$ See, e.g., George O. May, Financial Accounting ig (I943): "No one has a right to interpret a report of stewardship as though it were an invitation to invest."

${ }^{83}$ The much-criticized RESEARCF STUdy No. 3, for example, states that "accounting data are based on prices generated by past, present, or future exchanges which have actually taken place or are expected to" [id. at 6 (emphasis added)], and concludes that "current market price is . . . superior to past market price (acquisition cost) as a measure of the 'forgoing' or 'sacrifice' involved in the use or other disposition of the asset." Id. at 27. 
due to an increase in the price level. To state that accounting values are not economic values is simply to recognize that "one of the limitations affecting accounting is that it cannot simultaneously serve as a technology of cost and of valuation," and thus a balance sheet that in an accountant's opinion "fairly presents the financial position" of the corporation clearly does not, and indeed is not intended to, reflect the worthvalue of the assets. ${ }^{64}$

Of course, to state that accounting principles of valuation result in balance-sheet "values" that may have little or no relation to economic valuation is not necessarily to criticize the accounting valuation process; but it is necessary for the lawyer to understand accounting principles of valuation in order to attempt to determine the extent to which the law of dividends and financial accounting will look to and be governed by accounting principles of valuation of assets. To what extent, then, will the law look to accounting principles in valuing assets for the purpose of computing such items as surplus, depreciation, and earnings?

\section{Corporation Law Vaiuation Principles}

Historically, it is said, the courts have adopted and followed accounting principles in the valuation of assets for dividend purposes. ${ }^{65}$ Whether the one adopted and followed the other or the two just happened to coincide, it does appear that until three or four decades ago accounting and legal concepts of income and dividend regulation were generally in accord with the increase-in-net-worth concept of income. $^{68}$ In view of the fundamental shift of accounting emphasis in recent years

\footnotetext{
"Different degrees of understanding this important principle are illustrated by the following: ( 1 ) Merrinl Lynch, Pierce, Fenner \& Beane, How ro Read a Financial Report 3-4 (1947), stated that the item "Fixed Assets" on a balance sheet "gives the value of land, buildings and machinery and such movable things as trucks, furniture and hand tools. Historically, probably more sins were committed against this balance sheet item than any other." (Emphasis added.) (2) In its current edition, this same pamphlet states that the item "Fixed Assets" "represents those assets not intended for sale which are used over and over again in order to manufacture the product, display it, warehouse it, transport it. ... The generally accepted and approved method for valuation is cost less the depreciation accumulated to the date of the balance sheet. . . . The figure thus displayed is not intended to reflect market value at present or replacment cost in the future." Merrill Lynch, Pierce, FenNer \& SMith INc., How to Read a Financiad Report 8-9 (1962). (3) De Capriles, Modern Financial Accounting-Part I, 37 N.Y.U.L. REv. I00I, 1020-2I (I962), states, "[T] he costs applicable to the revenues of future accounting periods are 'deferred' to the future by the convention of designating them as assets. This is an accounting fiction ...." See also GiLMAN, op. cit. supra note 9, at 292-94, 297-98, 308-09; George O. May, Financial Accounting ch. V (1943).

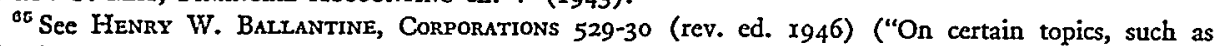
valuation, depreciation and depletion, the law impliedly adopts what may be termed good accounting practice"); 2 James C. Bonbright, The Valuation of Property 920 (I937) ("But in 'valuing' the assets [the courts in the law of dividends] . . . have adopted the accountants' so-called 'cost values,' although they would reject these valuations at once in other types of litigation"); HrLss, op. cit. supra note 7 , at 163 .

${ }^{\circ 0} \mathrm{See}$ authorities cited in note 37 supra. Determining the amount of profit available for dividends was formerly said to constitute the central accounting issue in a corporation. A. C. LITTLETON, Accounting Evaluation to xgoo, at 206 (I933).
} 
from the balance sheet to the income statement and the accompanying radical changes in principles of accounting for assets, the question may be restated as follows: to what extent will corporation laws, historically oriented in a "worth" concept of valuation, look to and follow accounting principles that are income-oriented and do not purport to render book valuations of any significance in a "worth" context?

At first glance, it might appear doubtful whether the law has changed its approach so as to keep pace with accounting developments. There is nothing explicit in the Model Business Corporation Act or any recent legislation to indicate that the law consciously intended to make the radical change from the historic legal concept of income as increase in balance-sheet surplus of worth-value to the modern accounting concept of income as an excess of realized money receipts over expired historic money costs.

The pattern of both old and recent corporation law statutes has been not to attempt to prescribe a theory of value or a detailed method of initially valuing acquired assets on the acquiring corporation's books. The Model Business Corporation Act is representative. ${ }^{67}$ It says nothing concerning carrying values for assets acquired for a consideration other than stock. It provides that shares are to be issued for a "consideration expressed in dollars" (section I7) without attempting to prescribe the principle of valuation. Section 18 deals with what constitutes proper consideration but not with how it is to be valued, and then provides that, in the absence of fraud, the judgment of the board of directors or the shareholders "as to the value of the consideration received" shall be conclusive. Again the statute does not specifically prescribe the concept of valuation intended. In the determination of the amount of stated capital and surplus arising upon the issue of shares, section $x$ speaks only in terms of the "consideration received." Surplus is defined in section 2 to mean "the excess of the net assets of a corporation over its stated capital," while net assets is defined to mean "the amount by which total assets" exceed total debts.

Here it is important to remember the distinction above alluded to among three different purposes the law has for valuing acquired assets and, consequently, among three possibly varying approaches to the problem of valuing the same assets:

First, the law prescribes that the value of assets acquired for stock must be determined in order to decide such matters as whether the stock is validly issued, fully paid, and nonassessable and whether previously existing shareholders of the issuing corporation have any complaint as to an inadequate value of assets received for securities given in exchange.

Second, the value of assets to be entered on the books (whether acquired

${ }^{\circ 7}$ The outstanding exception is the North Carolina statute, which imposes a "fair present value" test with respect to the comparison of assets with liabilities. N.C. GeN. STAT. $\$ \$ 55-50(c)(2), 55-52(c)(2)$ (1965). 
for stock or some other consideration) must be fixed in order to compute the amount of surplus or excess of net assets over capital of the issuing corporation under the applicable statutes relating to dividends and distributions.

Third, the assets must be entered at some dollar figure on a corporation's books in order to determine future exhaustion charges-for example, (I) the base upon which depreciation of fixed assets or amortization of intangibles will in the future be taken and (2) the "cost" of inventories that will be utilized in the cost-of-goods-sold formula. Such valuation determines the expected quantum of assets that will be "generated" or returned to the enterprise and that may not be paid out as dividends but will be returned tax-free from future revenues, and likewise determines in large part the amount of the expenses and deductions charged to revenue before computing the net income of the company.

Whether the valuation of assets for these three different purposes must be identical is a difficult question that is seldom discussed. It should be recognized that the first two valuation requirements are aimed at purely legal questions-watered stock, fairness of issue price vis-à-vis existing shareholders, and surplus available for distribution-while the third is formulated essentially in accounting terms relating to the computation of income.

The import of such provisions as section $x 8$ of the Model Act may throw some doubt upon the possibility of initially valuing assets for any of the three purposes at other than fair value to the corporation. That section is aimed principally at watered stock and the question of whether shares are fully paid and nonassessable; the objectives of the law seem clearly to require that the concept of worth-value be utilized for this purpose. However, since the conclusiveness of the valuation by the shareholders or directors under section I8 may be only for the purpose of fixing the extent of the outstanding obligation of the shareholders with respect thereto, this section may not necessarily mean that in fxing stated capital and computing surplus and future exhaustion charges, the book value of corporate assets must be the same worth-value so ascertained..$^{68}$

There does seem to be a direct and close relationship between valuation for stockassessability purposes and valuation for dividend purposes under an impairment-of-

${ }^{68} \mathrm{Cf}$. Gibson, supra note 30 , at 487 :

"But how do net assets exceed stated capital? In length, breadth, or thickness? None of these standards would satisfy the creditor, who is the person primarily to be protected, or even the stockholder, who is the person secondarily to be protected. Value is obviously the governing standard, though the Act refrains with studied care from any reference to that standard except in saying that a director shall not be personally liable for dividend distributions if believing in good faith that the assets have a 'value' at lease equal to the amount stated on the books. But one reference is enough. Value of fixed assets is thus the eventual and governing test of surplus and hence of permissible dividends under the Model Act."

But cf. id. at 488-90; Garrett, supra note 27, at 243 (footnote omitted): "Obviously, total assets are related to value; but in as much as directors are entitled under the Model Act to rely in good faith on book values, there was no need to specify how the assets were to be valued." 
capital test: ${ }^{69}$ it is logical that if shares are fully paid and nonassessable under section I8, then net assets on the books should at least equal stated capital, and the next dollar earned should yield surplus (net assets in excess of capital) available for dividend purposes. If shares were issued at a discount, then the deficit surplus (which the law would require to be made up out of earnings before a positive earned surplus could arise) should logically be the same dollar amount as the discount based upon fair value. Furthermore, in order for the shares not to become "watered" over the course of time by inadequate depreciation and amortization charges, it would seem that such charges should be based upon no less than the same values that determined the prior question of assessability and initially watered stock. To the extent that other classes of shareholders and security holders have a right to insist upon the receipt of a certain amount of consideration (fairly valued) upon the issue of stock, they may have an equal right to demand that exhaustion charges used in the determination of future income be sufficient to maintain the cushion represented as originally obtained. ${ }^{70}$

The r 962 amendment of section I9 of the Model Act, which was intended explicitly to authorize pooling-of-interests accounting, ${ }^{71}$ is an instance, however, where the statute specifically contemplates that assets will be put on the books at values other than the worth-values required to be fixed under section $x 8$. In a pooling of interests, prior book values are carried forward onto the books of the acquiring corporation $;^{72}$ such prior book values ordinarily have no conceivable relationship to fair value, cost, or any other currently meaningful figure, and in most instances today are far below the current worth-values that must be found in order to justify the issuance of the stock vis-à-vis the existing shareholder. May pooling-of-interests accounting be followed under applicable law where the par value of stock so issued is higher than such book values?73 If so, then worth-values (higher than book

\footnotetext{
${ }^{\circ}$ It should be noted that there is no such logical relationship where the dividend test is simply "net profits" or the equivalent, involving no comparison of assets with capital: assets may be taken at worth-value to determine whether stock is fully paid, but could be carried on the basis of some other value if income is more fairly reflected thereby. In this connection, see the discussion below of accounting for assets in a pooling of interests.

${ }^{70}$ Cf. Dean, op. cit. supra note 13, at 56; George O. May, Financial Accountino rot (1943).

${ }^{71}$ See Gibson, supra note 30, at 477-83. Cf. the 1959 Pennsylvania statute, Pa. Stat. ANn. tit. 15, $\$ 2852-704$ F (Supp. 1964); Hackney, Financial Accounting for Parents and Subsidiaries-A Netu Approach to Consolidated Statements, 25 U. PITT. L. REv. 9, I2-I8 (I963).

${ }^{72}$ See Baker, Dividends of Combined Corporations: Some Problems Under Accounting Research Bulletin No. 48, 72 HARv. L. REv. 494 (I959); Gibson, supra note 30; Hackney, supra note 71, at 12-18.

${ }^{78}$ A great many questions arise in such circumstances: $(I)$ Since net book values entered on the acquiring company's books would be less than par value of issued stock, would the stock be fully paid even if the directors duly declare that the acquired assets have worth-value equal to or in excess of par value? (2) What charge would be made for the difference between the aggregate net book value of assets acquired and the par value of stock issued? Would it be only to earned surplus carried forward from the acquired company, or to existing earned surplus, or even to existing capital surplus? What of a prohibition [implied, or express as in PA. STAT. ANN. tit. 15, $\$ 2852-704 \mathrm{D}$ (1958)] against all charges to capital surplus not specifically authorized? Could a charge to capital surplus be justified as a transfer from capital surplus to stated capital under PA. Stat. ANn. tit. I5, \$ 2852-614 (r958)? (3) If
} 
values) must be found that are at least equal to such par value in order to make the stock fully paid and nonassessable. May prior book values that are higher than fair value be carried forward (with resulting aggregate credits to capital and surplus)? In a jurisdiction where the law does not specifically authorize or contemplate ${ }^{74}$ pooling-of-interests accounting, the difficult and little recognized question arises whether acquired assets may be entered at any book values having no relationship to fair value or cost. Many statutes authorize (or may even require) pooling-of-interests accounting on a statutory merger or consolidation, but require purchase accounting on all business combinations effected by issuance of stock for assets or for stock. Even these, however, speak only in terms of what the resulting surplus is to be, and principles of asset valuation can again only be derived by inference.

In other instances of ordinary purchases of assets, it is not clear whether the law always requires valuation at cost, or just allows cost as the best evidence of the initial "value" that is used to determine liability of shareholders. In the case of an admitted bargain purchase, for example, are the assets acquired to be entered at cost or at real worth? To what extent will the law insist upon setting up capital contributions at objective fair value, rather than some lower value preferred by management with lower exhaustion charges? In the case of corporations in the regulated industries, do the applicable corporation laws allow the assets to be entered at cost to some predecessor corporation rather than cost to the corporation in question? Where a going concern is acquired (say for cash) and the purchase price is in excess of the fair value of the acquired assets, thus giving rise to goodwill, would there be any legal objection to initially entering the acquired assets at their fair value with an immediate write-off of goodwill to pre-existing surplus? ${ }^{75}$

the issued stock has an assets preference, would the spread between such assets preference and aggregate net book value of acquired assets result in a restriction upon surplus available for dividends? See Hackney, supra note $7 \mathrm{I}$, at 33 n.59.

${ }^{7 t}$ Since none of the statutes specifically deal with asset valuation in a pooling, the authorization to carry forward asset values is only impliedly sanctioned from the express provision authorizing the carry-forward of carned surplus. There is some question, in fact, whether the Model Act amendment even accomplishes its intended purpose. Section Ig contains the usual provision that consideration in excess of stated capital shall constitute capital surplus; the pooling amendment, in referring to "any amount that would otherwise constitute capital surplus under the foregoing provisions" (emphasis added), seems to proceed on the assumption that the dollar amount of the credit to surplus will be identical for either a purchase or a pooling, the only question being which surplus is to be credited. If, as stated by one of the draftsmen of the Model Act, the fair value of assets is the "eventual and governing test" of surplus and dividends under the Model Act (Gibson, supra note 30, at 487), how can prior book values be carried forward at all? The earlier Pennsylvania amendment, adding PA. Stat. ANN. tit. I5, $\$ 2852-704$ F (Supp. 1964 ), is clearer in that it expressly authorizes the carryforward of all the acquired company's earned surplus, which implies of necessity that the asset values giving rise to such quantum of earned surplus may also be carried forward. See Hackney, Financial Accounting for Parents and Subsidiaries-A New Approach to Consolidated Statements, 6 Corp. Prac. Comm. 309, 3I6-19 (1965) [reprinted with changes from 25 U. PITT. L. Rev. 8 (I963)].

${ }^{70}$ As recommended in Spacek, The Treatment of Goodwill in the Corporate Balance Sheet, J. Accountancy, Feb. 1964, p. 35, at 39-40. Cf. Kripke, $A$ Good Look at Goodwill in Corporate Acquisitions, 78 BANking L.J. 1028 (196r). 
Traditional principles of law, in requiring that assets purchased be entered initially on the books at their fair value, and the recent amendments and enactments attempting to accommodate the law to pooling-of-interests accounting, are in accord with "g.a.a.p." as to the valuation of assets. The law likewise appears to be in accord with such principles when it comes to valuing inventories that have appreciated in value because of unrealized appreciation or because of changes in the price level: the law, just as rigorously as accounting principles, has asserted the requirement of realization before recognition in the computation of income. ${ }^{70}$ Similarly, it would appear that the law is in accord with "g.a.a.p." when it requires depreciation to be taken ${ }^{77}$ and when it follows "g.a.a.p." of inventory valuation, particularly the requirement that inventories be written down to current values. ${ }^{78}$

Do these areas of accord between specific legal requirements and "g.a.a.p." mean that the law will follow all other accounting principles of valuation? Depreciation, for example, has been shown above to be in accounting a process of cost allocation, not valuation. But suppose an old building the cost of which has been completely depreciated on a company's books has continuing economic usefulness because of changed circumstances: is it to be valued at zero for dividend purposes? Or suppose a building has physically depreciated to half its original condition and one-half its cost has been depreciated to date but that changed neighborhood conditions-or a changed price level-give it a market or rental value equal in dollars to its original cost: what value is to be used for dividend purposes? Deferred charges were shown above to be properly carried forward as assets, in the discussion of the goingconcern postulate; but will the law allow without question the existence of un. amortized debt discount and expense to be included in ascertaining the existence of "surplus profits" for dividends? May work in process be valued in excess of immediately realizable market value in accordance with accounting principles? Is it legally proper to enter and value a receivable at the amount of the anticipated future cash receipts when the present realizable value of such receivable may be lower because of expected delay in payment and there may be some legal aspect of the transaction that presently bars the right to sue and obtain immediate judg. ment?

Will the law in a period of rapidly rising prices accept as sufficient exhaustion charges based on historical cost? Or might a court hold that recovery and maintenance of economic capital are necessary before income may be reported and distributed to shareholders?

\footnotetext{
${ }^{70}$ See Berks Broadcasting Co. v. Craumer, 356 Pa. 620, 625 n.3, 52 A.2d 57r, 574 n.3 (r947) (quoting a dictionary to the effect that realize means "convert into actual money"); BAKER \& CAnY, op. cit. supta note 25, at 1206-08; HenRy W. Ballantine, Corporations 54T (rev. ed. 1946); Hackney, The Financial Provisions of the Model Business Corporation Act, 70 HARv. L. Rev. 1357, 1380 \& n.108 (1957). Cf. Garrett, stipra note 27, at 243, 259.

${ }^{77}$ See Hizls, op. cit. supra note 7, at 209-r5; Henry W. Ballantine, Corporations 544 (rev. ed. 1946).

${ }^{78}$ See BAKER \& CARY, op. cit. supra note 25, at 1268-7r.
} 
A famous New York case has held that under a statute prohibiting any distribution by a corporation "unless the value of its assets remaining after the payment" thereof shall be equal to its liabilities including capital, assets may be computed upon the basis of present values. ${ }^{79}$ Under a statute or common law restriction speaking solely in terms of surplus, net assets in excess of capital, net profits, earned surplus, or surplus profits, or some such term, may unrealized appreciation be taken into account? Would it make any difference whether the unrealized appreciation were of inventories held for sale, or of supplies held for consumption, or of fixed assets held for productive use, or of investments of surplus funds, or of selfdeveloped goodwill?

It is commonly stated that an increase in asset values must be "realized" before it can be utilized in the computation of funds available for dividends, at least under statutory tests phrased in terms of profits or impairment of capital. ${ }^{80}$ On the other hand, many dicta and a few holdings indicate that whenever "value" is a factor to be considered in application of the legal test, some form of current worth-value is acceptable. ${ }^{81}$

It is believed that the difficulties to a court of law in abandoning the accounting approach to asset valuation are enormous and little recognized. It will be seen, for example, that it is not simply a question of taking the accountants' balance sheet and adding unrealized appreciation; as has been amply illustrated above, virtually all accounting valuation principles lead to book values having no certain or rational relationship to current worth-values, and some accounting "assets" might not be deemed an asset at all under a legal rule based upon realizable values. Any dividend or other legal rule of valuation that purports to be based on current worth-values must today recognize that no concept of valuation is so far removed from the objective sought as the concept found in "g.a.a.p." and that therefore virtually every single book entry going to make up the entire balance sheet would be subject to challenge and adjustment. The accounting balance sheet hardly seems even a likely place to start the process of worth-valuation.

\footnotetext{
${ }^{70}$ Randall v. Bailey, 23 N.Y.S.2d I73 (Sup. Ct. 1940), aff'd without opinion, 262 App. Div. 844, 29 N.Y.S.2d 512 (I94I), affd, 288 N.Y. 280, 43 N.E.2d 43 (I942). Complete discussions of the case and its implications may be found in BAKER \& CARY, op. cit. supra note 25, at Ir95 passim, and 2 David R. Herwitz, Business Planning 24I-62 passim (temporary ed. 1964).

${ }^{80}$ See authorities cited in note 76 supra.

${ }^{82}$ See the leading case of Randall v. Bailey, supra note 79, which quoted Brandeis, J., in Edwards v. Douglas, 269 U.S. 204, 214 (1925):

"The surplus account represents the net assets of a corporation in excess of all liabilities including its capital stock. 'This surplus may be 'paid-in surplus,' as where the stock is issued at a price above par. It may be 'earned surplus,' as where it was derived wholly from undistributed profits. Or it may, among other things, represent the increase in valuation of land or other assets made upon a revaluation of the company's fixed property."

See also Mountain State Steel Foundries, Inc. v. Commissioner, 284 F.2d 74r (4th Cir. I96o) (in statute prohibiting treasury stock purchases that would impair capital, actual values, rather than book figures, are critical to the inquiry); Baxter v. Lancer Indus., Inc., 213 F. Supp 92, 95 (E.D.N.Y. I963); 2 Herwitz, op. cit. supra note 79, at 255-62; Grorge C. Seward, Basic Corporate Practice 68-70 (I962).
} 
If it is up to a court or to a company's officers or attorney, then, to determine the current fair worth-value of a corporation's net assets, how is such valuation to be accomplished, and what concept of value is to be used? A few of the many difficult questions arising are as follows: ${ }^{82}$

(a) Are the assets to be valued on a piecemeal basis (or by classes), or is the over-all enterprise to be valued?

(b) If the enterprise is to be valued on an over-all basis-(i) How can this be done without reference to earnings and dividends? If they are considered, how are earnings to be computed, and how is the legality of dividends to be judged without reference to the revaluation being made? (ii) Is the aggregate market value of issued securities (if actively traded) the best evidence of over-all value (with appropriate discount for blockage, and so on)? If so, again, how can the reciprocal effect of earnings (and dividends) upon such market value of securities be eliminated? (iii) May self-developed goodwill be included as an asset? If not, how can such value be eliminated from the market price of securities or from the price a willing buyer would pay for the business as a whole? For dividend purposes, why distinguish between self-developed and purchased goodwill? (iv) How would such a new over-all valuation be distributed among the tangible assets of the corporation? Again, what of the excess, which can be allocated to nothing but self-developed goodwill?

(c) If the assets of the enterprise are to be separately revalued-(i) What concept of value is to be used-replacement value, or market value, or economic value (the present discounted value of future returns attributable to the asset), or appraisal value, or forced sale value, or historical cost adjusted for price-level variation? (ii) Should different concepts of value be used for such assets as inventories, which are held for sale in the ordinary course of business; investments, some marketable and some unmarketable, some having a definite business purpose and others being incomeproducing uses of excess cash; and fixed assets, which presumably could not be sold unless the enterprise were liquidated? ${ }^{83}$ How would you value deferred charges or capitalized advertising and promotion expense, which may well have considerable value-in-use or earnings potential but might yield nothing to a foreclosing creditor?

(d) Under any method of valuation-(i) What relationship would the new

\footnotetext{
${ }^{82}$ See Harvard Business School Accounting Round Table, op. cit. stipra note 49; James S. SCHINDLER, QuASI-REoRganization ch. IV (I958).

${ }^{83}$ Cf. Gibson, stepra note 30 , at $488-89$ :

"Within the realm of economic fact, the governing question must be in some such terms as whether a fixed asset, designed and useful for a specific function, really embodies value in any traditional or disposable sense apart from its successful exploitation in that function. Put the other way, the question is whether the fixed asset is not irretrievably committed to the specific enterprise and accordingly is, apart from earnings potential, rather a collection of liabilitics than an accumulation of values. ...

-...

"It has become a truism that value is a word of many meanings. The present suggestion is that, for the philosophy of corporate 'surplus,' it may have no meaning at all."
} 
values have to future depreciation charges, cost-of-goods-sold, and other income determination factors? Might the over-all valuation method be used to determine surplus available for dividends while the piecemeal valuation method might be used for exhaustion charges? Would dividends then no longer be a function of income? Or would income simply be the annual difference between aggregate net asset values? $^{84}$ (ii) What statements would be given to shareholders? Would a third set of books have to be kept (in addition to federal income tax returns and the audited financial statements)? (iii) How often would the revaluation have to be made? Every few years? Every year? Every dividend declaration date?

The subjective nature of revaluation-as attested by the range of experts' testimony as to estimated market values or appraised values possible-is widely asserted. ${ }^{\mathrm{SE}}$ The expense and difficulty involved for every corporation, of whatever size, constantly to revalue its assets argues against such a legal approach. The availability of funds for dividends under any such legal rule would no longer be a legal question capable of answer by the corporation's attorney, but simply a matter of business judgment or for determination by a valuation expert.

An increasing number of states have provisions similar to section 43 of the Model Act, authorizing reliance by the board of directors upon financial statements certified by the corporation's officers or independent public accountants. Such statutes argue strongly that valuation in accordance with modern "g.a.a.p." was intended. Persuasive also is the absence in the statutes of any guidance as to how the questions as to valuation raised above are to be answered; the myriad latent problems involved in abandoning accounting principles of valuation make it likely that courts would feel it necessary to defer to accounting principles. Especially is this true under the increasingly common "earned surplus" statutes recently enacted; it seems implicit in the term "earned surplus" that accumulated earnings (rather than surplus of worth-values) are intended to be the fundamental basis for dividends. ${ }^{38}$ It is, therefore, difficult to dispute the argument that accounting principles of asset valuation-having as their objective the correct computation of income-come closest to yielding that legal "earned surplus" or "surplus (other than capital surplus)" that is the basic source for dividends under most statutes.

It is not surprising to conclude that accounting principles can govern the legal issues of funds available for dividends, purchase of treasury stock, and other questions, except for the limited areas where there is a specific statute or other governing

\footnotetext{
${ }^{84}$ Cf. May, Business Combinations: An Alternate View, J. Accountancy, April 1957, p. 33, at 35: "A system of accounting which attempted to reflect changes in the value of an income stream in the determination of income would create an insoluble problem of circular reasoning."

${ }^{85}$ See, e.g., Harvard Business School Accounting Round Table, op. cit. supra note 49; Kohler, Why Not Retain Historical Cost?, J. Accountancy, Oct. I963, p. 35; Research Study No. 3, at 62 (comments of Carman G. Blough); id. at 8I (comments of William W. Werntz).

${ }^{80}$ The definition of earned surplus in the MoDEL ACT $\S 2(I)$ is taken almost verbatim from the accounting definition in Ternmology Bull. No. $\mathrm{I}$, at $\mathbf{I} 6$.
} 
legal principle. Bonbright, characterizing the then existing state of dividend law as "an anarchy of property law rather than a well-developed legal-economic institution," pointed to the clear need "for clear-cut distinctions between a valuation of assets designed to disclose values, and a pseudo-valuation designed as a mere first step in the ascertainment of realized income." ${ }^{37}$ Berle and Fisher wrote many years ago, "It may fairly be said that rules of accounting are for many purposes rules of law; or, conversely, that rules of law entail rules of accounting." J. Baker, one of the most discerning of legal commentators, some years ago forecast judicial reaction to the problems of valuation for dividend purposes as follows:

The suggestive factor is that, whether we like it or not and whether we are wholly aware of it or not, the accountants may be making our law. . . . If the case is well tried, with submission of accounting literature as evidence and accounting testimony or depositions, what accountants of standing do and say may make the decision.... [G]ood accounting practice may be enough even though it falls short of being uniform accounting practice. ${ }^{89}$

${ }^{87} 2$ James C. Bonbright, The Valuation of Property 912 (1937).

${ }^{88}$ Berle \& Fisher, Elements of the Law of Business Accounting, 32 CoLUM. L. REv. 573, 578 (1932).

${ }^{80}$ Baker, Hildebrand on Texas Corporations-A Review, 21 Texas L. Rev. 169, Igo (1942), quoted with approval in HeNRY W. BaLlantine, Corporations 529 (rev. ed. I946). One of the most difficult aspects of the law's adopting "g.a.a.p." as a fundamental guide for the ascertainment of business income (and determination of the related legal notions of earned surplus and capital impairment) is the wide variation in acceptable principles that exists today. Can accounting principles that do not require a reasonable degree of uniformity be good enough for the law to adopt? The dramatically extensive effect of variations in accounting principles has been well documented. See, e.g., Netws Report, J. Accountancy, March 1958 , p. 20 (changes in accounting principles converted a $\$ 745,000$ profit to a $\$ 455,000$ loss and caused a charge to earned surplus of $\$ 6,307,1_{51}$ ); Hayes, Accounting Principles and Investment Analysis, supra, pp. 752-7r. An important instance of permissible variation with incredible effects upon future reported income occurs in the case of business combinations, where the published criteria for distinguishing a purchase from a pooling appear to have broken down completely. Wyatt reports that by 1960 "most business combinations apparently could be accounted for cither under the purchase concept or under the pooling concept, and either treatment would be held to be in accordance with generally accepted accounting principles." ARThUR R. WYATT, A Critical Study of Accounting For Business Combinations 15 (AICPA Research Study No. 5, 1963). In one instance assets that would have been valued at $\$ 97,000,000$ in a purchase were carried forward at a net book value of $\$ 25,173,099$ (with earned surplus of $\$ 12,867,308$ also carried forward). Id. at 29-30. See also Kripke, supra note 75 .

A court might well balk at a concept of income that would allow one accountant to approve a substantial reported net income while another could approve a substantial reported net loss for the same period. On the other hand, a court should recognize that "business income" by its nature can not be a precise figure, except perhaps over the life of an enterprise; variations in accounting principles in most instances result only in the shifting of periodic income figures from one period to another, but cumulatively, the net income for a number of successive periods is not apt to vary significantly. (An exception would occur if price-level adjustments became permissive; the resulting variation would tend to grow cumulatively larger as long as the price level continued either up or down. Another exception occurs in the pooling-versus-purchase area, where the decision made at the time of the combination determines future net income so long as the assets remain on the books.)

Much of the controversy in the accounting profession today is over the primacy of the objective of consistency (for a single enterprise) as against the objective of comparability (for all enterprises in an industry), but for legal purposes it would appear that the principle of consistency is always an imperative while uniformity, although desirable, would be necessary only in the few cases where long-run cumulative results are affected. Since accounting involves to a large degree questions of judgment, permissible variations in accounting principles would seem to raise essentially the same legal question 
If the above conclusion is accepted, it means that today principles of valuation for state corporation law purposes, fundamentally based upon cost (or useful cost), are to be interpreted as aimed not at fixing anything resembling actual present worth but rather at setting up the flow of cost factors so as most accurately to reflect current income in accordance with generally accepted principles of accounting. This conclusion is most obviously true under statutory dividend rules laid down in terms of profits or net income; but in addition it also means that a statutory balance-sheetsurplus test that may appear to be based upon fair net worth of assets has instead, through the principles of valuation followed, been turned into a retained-earnings test based essentially upon accumulated income as computed in accordance with generally accepted accounting principles.

If the conclusion is sound, it also suggests that lawyers must be diligent to examine, analyze, publicly criticize, and otherwise contribute to the formulation of accounting principles. ${ }^{90}$

as the permissible area of conduct allowed by the "business judgment" rule in reviewing and assessing management conduct: a court will not substitute its own decision for that of management so long as reasonable diligence and care have been exercised.

${ }^{\circ 0}$ Professor Herwitz's comment on Research Bulz. No. 45, pertaining to accounting for long-term construction contracts, supra note 50, and Homer Kripke's article on goodwill, supra note 75 , are outstanding exceptions to the paucity of legal comments aimed at contributing to the development of accounting principles. The opportunity in the past for direct participation by lawyers in the process of developing accounting principles has not been substantial. Indeed, the promulgation of $5 \mathrm{I}$ Research Bulletins and 4 Terminology Bulletins by the Committee on Accounting Procedure (some 20 members) and Committee on Terminology ( 3 members) of the AICPA seems to indicate that relatively few accountants had any substantial voice therein. Of interest, by comparison, is the practice of the American Law Institute in submitting drafts of its Restatements and other projects to its entire membership for approval or rejection on a line-by-line basis. The presence of lawyers on the project advisory committees appointed to serve as advisors and consultants to each of the AICPA's Accounting Research Studies is noted with approval. The AICPA has stated it plans to have greater participation by individuals and groups both within and without the public accounting profession. Editorial, J. Accountancy, Dec. $x 958$, p. 27 , at 28 . Still needed is increased recognition by lawyers generally of their obligation "to become acquainted with the lore and literature of their accounting brethren." Herwitz, supra note 50, at 449. 